\title{
Effects of Organic Content on Anaerobic Biodegradability of Sludge Generating from Slaughterhouse
}

\author{
Seung-Yong $\mathrm{Oh}^{1}$, Ho Kim ${ }^{2}$, Chang-Hyun Kim${ }^{1}$, Seung-Hwan $\mathrm{Kim}^{1}$, and Young-Man Yoon ${ }^{1}$ * \\ ${ }^{1}$ Biogas Research Center, Hankyong National University, Anseong, 456-749, Republic of Korea \\ ${ }^{2}$ Institute for Advanced Engineering, Yongin, Gyeonggi, 449-863, Republic of Korea
}

(Received: August 5 2013, Accepted: August 14 2013)

This study was carried out to investigate the effect of organic content level on ultimate methane potential and anaerobic biodegradability of substrate by biochemical methane potential assay. Three organic matters (whole sludge and liquid and solid fraction of sludge) of the same origin, which had different organic contents, were fermented at the batch anaerobic reactor for 70 days. Ultimate methane potential and anaerobic biodegradability were determined by the terms of volatile solid (VS) and chemical oxygen demand (COD). Volatile solid contents of whole sludge and solid and liquid fraction of sludge were 2.4, 18.8, and $0.2 \%$ and COD were 5.3, 30.4, and $0.5 \%$, respectively. Ultimate methane potentials $\left(B_{u}-V S\right)$ and anaerobic biodegradability $\left(D_{V S}\right)$ determined by VS content were $0.5 \mathrm{Nm}^{3} \mathrm{~kg}^{-1}-\mathrm{VS}_{\text {added }}, 76.3 \%$ for whole sludge, $0.5 \mathrm{Nm}^{3}$ $\mathrm{kg}^{-1}-\mathrm{VS}_{\text {added }}, \mathbf{7 6 . 3 \%}$ for the liquid fraction of sludge, and $0.6 \mathrm{Nm}^{3} \mathrm{~kg}^{-1}-\mathrm{VS}_{\text {added, }}, \mathbf{7 7 . 0 \%}$ for the solid fraction of sludge. Ultimate methane potentials $\left(\mathrm{B}_{\mathrm{u}}-\mathrm{COD}\right)$ and anaerobic biodegradability $\left(D_{C O D}\right)$ determined by $\mathrm{COD}$ were $0.2 \mathrm{Nm}^{3} \mathrm{~kg}^{-1}-\mathrm{COD}_{\text {added, }}, 73.4 \%$ for whole sludge, $0.2 \mathrm{Nm}^{3} \mathrm{~kg}^{-1}-\mathrm{COD}_{\text {added }}, 74.0 \%$ for the liquid fraction of sludge, and $0.33 \mathrm{Nm}^{3} \mathrm{~kg}^{-1}-\mathrm{COD}_{\text {added, }}, 99.1 \%$ for the solid fraction of sludge. In conclusion, ultimate methane potential and anaerobic biodegradability given by the VS term showed more reasonable results because COD might be underestimated by the interference of $\mathrm{NH}_{4}{ }^{+}$in the case of highly concentrated organic material.

Key words: Biochemical methane potential, Anaerobic biodegradability, Anaerobic digestion, Volatile solid, Chemical oxygen demand

Ultimate methane potential and anaerobic biodegradability given by the VS term showed more reasonable results, COD might be underestimated by the interference of $\mathrm{NH}_{4}{ }^{+}-\mathrm{N}$ in highly concentrated organic material.

\begin{tabular}{|c|c|c|c|c|}
\hline \multirow{2}{*}{ Sample } & \multicolumn{2}{|c|}{ Ultimate methane potential } & \multicolumn{2}{|c|}{ Anaerobic biodegradability } \\
\hline & $\mathrm{B}_{\mathrm{u}}-\mathrm{VS}$ & $\mathrm{B}_{\mathrm{u}}-\mathrm{COD}$ & $D_{V S}$ & $D_{C O D}$ \\
\hline & $\mathrm{Nm}^{3} \mathrm{~kg}^{-1}-\mathrm{VS}_{\text {added }}$ & $\mathrm{Nm}^{3} \mathrm{~kg}^{-1}-\mathrm{COD}_{\text {added }}$ & $\begin{array}{c}----- \\
-\cdots\end{array}$ & 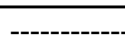 \\
\hline Sludge & $0.52 \mathrm{a}$ & $0.24 \mathrm{a}$ & $76.31 \mathrm{a}$ & $73.43 \mathrm{a}$ \\
\hline Liquid fraction & $0.52 \mathrm{a}$ & $0.23 \mathrm{a}$ & $76.30 \mathrm{a}$ & $74.01 \mathrm{a}$ \\
\hline Solid fraction & $0.55 \mathrm{a}$ & $0.33 b$ & $77.04 \mathrm{a}$ & $99.06 \mathrm{~b}$ \\
\hline
\end{tabular}

*Corresponding author : Phone: +82316705665, Fax:+82316705666, E-mail: yyman@hknu.ac.kr

${ }^{\S}$ Acknowledgement: This research was supported by Bio-industry Technology Development Program, Ministry for Food, Agriculture, Forestry and Fisheries, Republic of Korea (Project No. 311005-3). 


\section{Introduction}

가축분뇨, 하수슬러지, 작물잔사 등 유기성 바이오매스 를 이용하여 바이오가스를 생산하는 혐기소화 기술은 세계 적으로 널리 실용화된 기술이다. 우리나라에서는 기후변화 와 화석연료 고갈에 대응하여 대체에너지의 생산과 이산화 탄소 $\left(\mathrm{CO}_{2}\right)$ 감축 측면에서 혐기소화 기술에 대한 관심이 증 가하고 있다. 혐기소화 기술은 각종 유기성 바이오매스를 연료가치를 지니는 메탄 $\left(\mathrm{CH}_{4}\right)$ 으로 전환시키는 기술이다. 따 라서 혐기소화에 의한 메탄생산효율은 일차적으로 원료로 이용되는 유기성 바이오매스의 메탄생산포텐셜(biochemical methane potential)에 의해 결정된다.

메탄생산포텐셜은 유기물의 혐기적 분해율의 지표로서 활용되고, 혐기소화조 효율과 경제성에 영향을 미치는 주요 인자로서 혐기소화 시설의 설계와 관리에 있어 가장 중요한 인자이다. 따라서 국내외 많은 연구자들은 다양한 유기성 바이오매스에 대한 메탄생산포텐셜 측정 방법과 결과들을 보고하고 있다 (Angelidaki et al., 2009, Kim et al., 2010, Shin et al., 2011). 메탄생산포텐셜 측정은 Hungate (1969) 가 혐기성 미생물의 배양방법을 개발한 이후 Owen et al. (1979)에 의해 고안된 방법으로 회분식 혐기 반응기를 이용 하여 투입 기질에 대한 메탄가스의 생산 수율을 산출한다. 그러나 메탄생산포텐셜의 측정은 사용된 장비의 종류, 혐기 미생물 접종액과 기질의 물리화학적 특성, 접종액의 미생물 활성도, 배지의 양분균형, 반응기의 $\mathrm{pH}$, 반응기 내 여유 공 간(Head space)의 정도, 교반방법 등 메탄생산포텐셜 분석 환경의 영향을 받는다 (Shelton and Tiedje, 1984, Angelidaki et al., 2009, Shin et al., 2011). 특히 투입 기질의 물리화 학적 특성은 메탄생산포텐셜을 결정하는 가정 중요한 인자 이다 (Kim et al., 2012).

독일과 미국에서는 유기물의 메탄생산포텐셜과 혐기적 유기물 분해율의 측정을 위하여 각각 VDI4630 (2006)과 ASTM E2170-01 (2008)과 같은 표준분석방법을 마련하여 운영하고 있다. 그러나 국내에는 아직 유기물의 메탄생산포 텐셜의 측정을 위한 표준 분석 방법이 마련되어 있지 않은 상황이다. 독일의 VDI4630 (2006)은 회분식 혐기 반응기에 서 생산되는 메탄의 수율을 산출하는데 있어 반응기의 운전 온도, 반응기 내 여유공간(Head space), 바이오가스의 압 력, 수분함량, $\mathrm{CH}_{4}$ 과 $\mathrm{CO}_{2}$ 농도, 접종액(Inoculum)에 의한 가스발생량, 분석시료의 회분(Ash) 함량 등을 보정하여 메 탄생산포텐셜 및 혐기적 유기물 분해율을 계산한다. 메탄가 스의 생산 수율은 일반적으로 표준상태 $\left(0^{\circ} \mathrm{C}, 1\right.$ 기압)에서 투 입 휘발성고형물 (volatile solid)에 대한 메탄 생산량 $\left(\mathrm{Nm}^{3}\right.$ $\mathrm{kg}^{-1}-\mathrm{VS}$ ) 또는 투입 화학적 산소요구량 (chemical oxygen demand; $\mathrm{COD})$ 에 대한 메탄 생산량 $\left(\mathrm{Nm}^{3} \mathrm{~kg}^{-1}-\mathrm{COD}\right)$ 으로 나타낸다.
일반적으로 메탄생산포텐셜의 산출단위는 연구자들의 연 구목적과 원료의 이화학적 특성에 따라 채택·이용하고 있으 나, 휘발성 고형물의 경우 원료에 포함되어 있는 유기물의 구성원소인 탄소 $(\mathrm{C})$, 수소 $(\mathrm{H})$, 산소 $(\mathrm{O})$, 질소 $(\mathrm{N})$, 황 $(\mathrm{S})$ 의 총량을 나타내는 반면, 화학적 산소요구량의 경우 유기 물 중 탄소 $(\mathrm{C})$ 를 산화시키는데 요구되는 산소 $\left(\mathrm{O}_{2}\right)$ 의 양으로 원료 중의 유기탄소의 양을 대표한다. 그러므로 휘발성 고 형물 함량 기준의 메탄생산 포텐셜과 혐기적 분해율은 원료 중의 유기물 단위 질량당 메탄생산수율과 유기물의 혐기적 분해율을 나타내게 되며, 화학적 산소요구량 기준의 메탄생 산 포텐셜과 혐기적 분해율은 원료 중의 유기탄소 단위 질 량당 메탄생산수율과 유기탄소의 혐기적 분해율을 대표한 다. 따라서 본 연구에서는 기질의 유기물 함량 수준과 유기 물의 표현방법에 따른 혐기적 유기물 분해율의 변화를 파악 하고자 하였으며, 이를 위해 발생 특성과 유래가 동일하나 유기물 함량을 달리하는 유기성 기질들에 대하여 메탄생산 포텐셜을 측정하였으며, 휘발성 고형물과 화학적 산소요구 량 기준으로 산출한 기질의 혐기적 유기물 분해율을 비교 평가하였다.

\section{Materials and Methods}

공시시료 본 연구에서는 유래가 동일하면서 유기물 함 량 수준을 달리하는 유기성 기질로서 도계가공장 (충북 진 천 소재)에서 발생하는 폐수처리 슬러지와 폐수처리 슬러지 를 고액분리하여 얻은 탈수여액과 탈수케익을 시험에 공시 하였다.

\section{이론적 메탄생산포텐셜 (Theoretical methane potential;}

$\mathbf{B}_{\mathrm{th}}$ ) 이론적 메탄생산포텐셜은 Boyle(1976)의 혐기적 유기 물 분해 반응식, 유기물 산화 반응식 (식 1, 식 3)을 이용하 여 시료의 원소분석결과로부터 화학양론적으로 계산하였으 며, 표준상태 $\left(0^{\circ} \mathrm{C}, 1\right.$ 기압)에서 휘발성 고형물 함량을 기준으 로 산출하는 이론적 메탄생산포텐셜은 식 2 와 같으며, 화학 적 산소요구량을 기준으로 산출하는 이론적 메탄생산 포텐 셜은 식 4 와 같다. 화학적 산소요구량을 기준의 이론적 메 탄생산 포텐셜은 $0.35 \mathrm{Nm}^{3} \mathrm{~kg}^{-1}-\mathrm{COD}_{\text {added }}$ 이다.

$$
\begin{aligned}
& C_{a} H_{b} O_{c} N_{d} S_{e}+\left(a-\frac{b}{4}-\frac{c}{2}+\frac{3 d}{4}+\frac{e}{2}\right) H_{2} O \\
& \rightarrow\left(\frac{a}{2}+\frac{b}{8}-\frac{c}{4}-\frac{3 d}{8}-\frac{e}{4}\right) C_{4}+ \\
& \left(\frac{a}{2}-\frac{b}{8}+\frac{c}{4}+\frac{3 d}{8}+\frac{e}{4}\right) C O_{2}+d N H_{3}+e H_{2} S
\end{aligned}
$$




$$
\begin{aligned}
& B_{t h-V S}\left(\mathrm{Nm}^{3} \mathrm{~kg}^{-1}-V S_{\text {added }}\right)=22.4 \times \\
& {\left[\frac{(4 a+b-2 c-3 d-2 e) / 8}{12 a+b+16 c+14 d+32 e}\right]} \\
& C_{a} H_{b} O_{c} N_{d} S_{e}+\left(a+\frac{b}{4}-\frac{c}{2}-\frac{3 d}{4}-\frac{e}{2}\right) O_{2} \rightarrow a C O_{2}+ \\
& \left(\frac{b}{2}-\frac{3 d}{2}-e\right) H_{2} O+d N H_{3}+e H_{2} S \\
& B_{t h-C O D}\left(N m^{3} k g^{-1}-C O D_{\text {added }}\right)=22.4 \times \\
& {\left[\frac{\left(\frac{4 a+b-2 c}{8}\right)}{\left(a+\frac{b}{4}-\frac{c}{2}-\frac{3 d}{4}-\frac{e}{2}\right) \times 32}\right]=0.35}
\end{aligned}
$$

\section{실험적 메탄생산포텐셜 시험 (Biochemical methane} potential assay ; BMP assay) 메탄생산포텐셜 시험에 사 용한 접종액은 (Inoculum; I)은 경기도 안성에 위치하는 한 경대학교 바이오가스 상용화 연구시설에서 발생하는 혐기 소화액을 채취하였으며, 채취한 혐기소화액은 $2 \mathrm{~mm}$ 체를 통과시킨 후, $38^{\circ} \mathrm{C}$ 항온 배양기에서 배양하여 소화액 중의 이분해성의 유기물과 잔여가스를 충분히 제거하여 접종액 으로 사용하였다. 투입기질(Substrate; S)은 기질의 휘발성 고형물 함량과 접종액의 휘발성 고형물 함량의 비율 (S/I ratio)이 0.3 이 되도록 조정하여 투입하였다. 회분식 반응기 는 처리구당 3 반복으로 serum bottle을 이용하였으며, 반응 기의 용적(Total volume)은 $160 \mathrm{~mL}$ 이며, 유효용적(Working volume)은 $80 \mathrm{~mL}$, 상층부 여유공간 (Head space)은 $80 \mathrm{~mL}$ 로 하였다. 반응기의 상층부 여유공간은 $\mathrm{N}_{2}$ 가스로 충진 후 고무마개와 알루미늄 캡을 이용하여 2중으로 밀폐시켰으며, $38^{\circ} \mathrm{C}$ 항온 배양기에서 일일 1 회 손으로 반응기를 흔들어 교 반하면서 70일간 배양하였다. 또한 접종액에서 발생하는 메 탄 가스를 보정하기 위하여 접종액만을 투입한 3반복의 혐 기 반응기를 시료와 동일한 조건에서 운영하였다. 접종액의 이화학적 성상은 Table 1 과 같다.

메탄생산 포텐셜 시험 중에 발생하는 바이오가스는 식 5 와 같이 온도와 수분을 보정하여 표준상태 $\left(0^{\circ} \mathrm{C}, 1\right.$ 기압)에서 의 건조가스 (dry gas)로 환산하여 누적 메탄생산곡선을 구
하였으며, 식 5 에서 $\mathrm{V}_{\mathrm{dry}}$ gas 는 건조 가스의 부피, $\mathrm{V}_{\text {wet gas at }}$ $\mathrm{T}^{\circ} \mathrm{C}$ 는 반응기 운전온도에서의 습윤가스의 부피, $\mathrm{T}$ 는 반응기 의 운전온도, $\mathrm{P}$ 는 가스의 부피측정 당시의 기압, $\mathrm{P}_{\mathrm{T}}$ 는 $\mathrm{T}^{\circ} \mathrm{C}$ 에서의 포화수증기압 $(\mathrm{mmHg})$ 이다. 본 연구에서는 $\mathrm{P}$ 를 760 $\mathrm{mmHg}$ 로 간주하고 $\mathrm{P}_{\mathrm{T}}$ 는 $38^{\circ} \mathrm{C}$ 에서의 포화수증기압으로 계 산하였다.

$$
V_{\text {dry gas }}=V_{\text {wet gas at } T^{\circ} C} \times \frac{273}{(273+T)} \times \frac{\left(P-P_{T}\right)}{760}
$$

메탄생산포텐셜 시험을 통한 시험기질의 최대 메탄생산 포텐셜 (Ultimate methane potential; $\mathrm{B}_{\mathrm{u}}$ )은 Modified Gompertz model (식 6)을 이용하여 산출하였다. Modified Gompertz model에서 $M$ 은 누적 메탄 생성량 $(\mathrm{mL}), P$ 는 최 대 메탄 생성량 $(\mathrm{mL}), R_{m}$ 은 메탄 생성 속도 $\left(\mathrm{mL}\right.$ day $\left.^{-1}\right), \lambda$ 는 지체성장시간 (lag phase time, days), $t$ 는 혐기배양시간 (day)을 의미한다.

$M=P \times \exp \left[-\exp \frac{R_{m}}{P}(\lambda-t) e+1\right]$

\section{혐기적 유기물 분해율(Anaenobic biodegradability) 평가} 기질의 혐기적 유기물 분해율은 VDI4630 (2006)의 유기물 분해율 계산 방식에 따라 평가하였으며, 휘발성 고형물 기 준의 혐기적 유기물 분해율 $\left(D_{V S}\right)$ 은 식 7과 같으며, 화학적 산소 요구량 기준의 혐기적 유기물 분해율 $\left(D_{C O D}\right)$ 은 식 8 과 같다. 식 7에서 $D_{V S}$ 는 $\mathrm{VS}$ 기준 혐기적 유기물 분해율 (\%), $V_{\text {drybiogas }}$ 는 바이오가스의 부피 $\left(\mathrm{Nm}_{\text {dry gas }}^{3}\right), C_{C H_{4}+C O_{2}}$ 는 바이오가스 중 메탄과 이산화탄소의 질량 분율 $(\mathrm{kg}$ $\left.\mathrm{Nm}^{-1}\right), m_{\text {substrate }}$ 는 기질의 질량 $(\mathrm{kg}), V S_{\text {substrate }}$ 는 투입기 질의 VS 농도 $\left(\mathrm{g} \mathrm{g}^{-1}\right), V F A s_{\text {substrate }}$ 는 투입기질의 VFA 농 도 $\left(\mathrm{g} \mathrm{g}^{-1}\right), 0.93$ 은 투입 VS 중 이론적인 바이오가스 전환율

\begin{tabular}{|c|c|c|c|c|c|c|c|}
\hline & $\mathrm{pH}$ & $\mathrm{TS}^{\dagger}$ & $\mathrm{VS}^{\ddagger}$ & $\mathrm{TCOD}^{\S}$ & $\mathrm{TN}^{\pi}$ & $\mathrm{NH}_{4}{ }^{+}-\mathrm{N}$ & Alkalinity \\
\hline & - & & --------- & $\%(\mathrm{w} / \mathrm{v})$ & ------ & & $\%$ as $\mathrm{CaCO}_{3}$ \\
\hline Inoculum & 8.8 & $\begin{array}{c}2.61 \\
(0.06)^{\phi}\end{array}$ & $\begin{array}{c}1.44 \\
(0.02)\end{array}$ & $\begin{array}{c}2.50 \\
(0.08)\end{array}$ & $\begin{array}{c}0.45 \\
(0.01)\end{array}$ & $\begin{array}{c}0.34 \\
(0.01)\end{array}$ & $\begin{array}{c}1.91 \\
(0.14)\end{array}$ \\
\hline
\end{tabular}
을 나타내며, 식 8 에서 $D_{C O D}$ 은 $\mathrm{COD}$ 기준 혐기적 유기물 분해율 $(\%), x_{\mathrm{CH}_{4}}$ 는 바이오가스 중 메탄의 농도 $(\%, \mathrm{v} / \mathrm{v})$, $M_{\text {substrate }}$ 는 투입기질의 질량 $(\mathrm{kg}), C O D_{\text {substrate }}$ 는 투입기질 의 $\mathrm{COD}$ 함량 $\left(\mathrm{g} \mathrm{g}^{-1}\right), 0.32$ 는 투입 $\mathrm{COD}$ 중 이론적 메탄 전 환율을 나타낸다.

Table 1. Chemical characteristics of inoculum.

${ }^{\dagger}$ Total solid content, ${ }^{\ddagger}$ Volatile solid content, ${ }^{\S}$ Total chemical oxygen demand, "Total nitrogen content, ${ }^{\S}$ Values in parentheses are standard deviations. 


$$
\begin{aligned}
D_{V S} & =\frac{V_{\text {dry biogas }} \times C_{C H_{4}+C O_{2}} \times 100(\%)}{m_{\text {substrat }} \times\left(V S_{\text {substrate }}+V F A s_{\text {substrate }}\right) \times 0.93} \\
D_{C O D} & =\frac{V_{\text {dry biogas }} \times x_{C H_{4}} \times 100(\%)}{0.32 \times M_{\text {substrate }} \times C O D_{\text {substrate }}}
\end{aligned}
$$

분석방법 회분식 혐기반응기의 바이오가스 발생량 측정 은 $2 \%$ 황산에 resazurin $0.1 \%$ 를 함유하는 수주차식 가스량 측정기를 사용하였으며 (Willams, 1996; Beuvink, 1992), 바이 오가스의 가스성분분석은 TCD (Thermal conductivity detector) 가 장착된 Gas chromatography (Clarus 680, PerkinElmer, USA)를 이용하였다. 컬럼은 HayesepQ packed column (3 $\mathrm{mm} \times 3 \mathrm{~m}, 80 \sim 100$ mesh size)을 이용하였으며, 고순도의 아르곤(Ar) 가스를 이동상으로 사용하여 flow $30 \mathrm{~mL} \mathrm{~min}{ }^{-1}$ 의 운전상태에서 주입부 (Injector) 온도 $150^{\circ} \mathrm{C}$, 컬럼부 (Column oven) $90^{\circ} \mathrm{C}$, 검출부 (Detector) $150^{\circ} \mathrm{C}$ 에서 분석하 였다 (Sorensen et al., 1991). 기질의 전 원소분석은 원소분 석기 (EA1108, Thermo Finnigan, CA)를 사용하였으며, 총 고형물(Total solid; TS), 휘발성 고형물(Volatile solid; VS), 화학적 산소 요구량(Chemical oxygen remand; COD), 암모 니아성 질소 $\left(\mathrm{NH}_{4}{ }^{+}-\mathrm{N}\right)$, 총질소 (Total nitrogen; $\mathrm{TN}$ ) 등은 Standard methods (APHA, 1998)에 따라 3반복으로 분석하 였다. 각각 $\mathrm{VS}$ 함량과 $\mathrm{COD}$ 함량을 기준으로 하는 유기물의 혐기적 분해율은 3 반복의 자료를 수집하여 SAS package (SAS, 1999)를 이용하여 Duncan의 다중검정법에 의해 $95 \%$ 유의수준으로 분석하였다.

\section{Results and Discussion}

\section{공시시료의 이화학성 공시한 시료의 이화학성은} Table 2와 같다. 채취한 슬러지의 이화학성은 $\mathrm{pH}$ 는 6.7이었 으며, TS와 VS는 각각 $2.76,2.40 \%(\mathrm{w} / \mathrm{v})$ 으로 나타났다. 고 액분리를 통해 얻어진 슬러지의 고상과 액상의 $\mathrm{pH}$ 는 각각 $7.4,7.2$ 로 비슷하였으며, 슬러지의 $\mathrm{pH}$ 와 비교하여 약간 상 승한 것은 고액분리과정에서 사용한 응집제에 영향으로 생 각된다. 슬러지 고상의 TS와 VS는 $21.00,18.77 \%$ 로 나타났 으며, 슬러지 액상의 TS와 VS는 0.26, 0.21\%를 나타내었다. $\mathrm{VS}$ 함량과 대비되는 TCOD 함량은 슬러지, 고상, 액상에서 각각 $5.29,0.47,30.35 \%$ 를 나타났고, $\mathrm{TN}$ 의 함량 또한 슬러 지, 고상, 액상에서 각각 $0.21,0.20,1.39 \%$ 로 나타나 대부 분의 유기물이 고액분리를 통해 고상에 축적되었다.

\section{이론적 메탄생산포텐셜(Theoretical methane potential;}

$\mathbf{B}_{\mathrm{th}}$ ) 공시시료의 이론적 메탄생산포텐셜은 공시시료의 원 소분석 결과로부터 산출되었으며, 슬러지의 경우 $0.81 \mathrm{Nm}^{3}$ $\mathrm{kg}^{-1}-\mathrm{VS}_{\text {added }}$ 로 나타났으며, 슬러지 고상의 경우 $0.79 \mathrm{Nm}^{3}$ $\mathrm{kg}^{-1}-\mathrm{VS}_{\text {added }}$ 로 나타났다 (Table 3). 공시시료의 원소분석 결과 슬러지에서의 산소와 질소 함량은 $14.6,5.2 \%(\mathrm{w} / \mathrm{w})$ 로 나타났으며, 슬러지 고상에서의 산소와 질소 함량이 5.0, $14.0 \%(\mathrm{w} / \mathrm{w})$ 로 나타나 슬러지 고상에서의 질소 축적을 확 인할 수 있었다.

\begin{tabular}{|c|c|c|c|c|c|c|c|c|c|}
\hline Sample & $\mathrm{pH}$ & $\mathrm{TS}^{\dagger}$ & $\mathrm{VS}^{\ddagger}$ & $\mathrm{TCOD}^{\S}$ & $\mathrm{SCOD}^{\pi}$ & $\mathrm{TN}^{\phi}$ & $\mathrm{NH}_{4}{ }^{+}-\mathrm{N}$ & $\mathrm{SS}^{\jmath}$ & Alkalinity \\
\hline & - & ---- & ---------- & ----- \% & v) ------ & ------- & ----- & $\mathrm{g} \mathrm{L}^{-1}$ & $\%$ as $\mathrm{CaCO}_{3}$ \\
\hline Sludge & 6.7 & $\begin{array}{c}2.76 \\
(0.04)^{\sqrt{J J}}\end{array}$ & $\begin{array}{c}2.40 \\
(0.01)\end{array}$ & $\begin{array}{c}5.29 \\
(0.51)\end{array}$ & $\begin{array}{c}0.33 \\
(0.01)\end{array}$ & $\begin{array}{c}0.21 \\
(0.01)\end{array}$ & $\begin{array}{c}0.04 \\
(0.01)\end{array}$ & $\begin{array}{c}25.2 \\
(0.34)\end{array}$ & $\begin{array}{c}0.18 \\
(0.05)\end{array}$ \\
\hline Liquid fraction & 7.4 & $\begin{array}{c}0.26 \\
(0.01)\end{array}$ & $\begin{array}{c}0.21 \\
(0.01)\end{array}$ & $\begin{array}{c}0.47 \\
(0.05)\end{array}$ & $\begin{array}{c}0.09 \\
(0.01)\end{array}$ & $\begin{array}{c}0.20 \\
(0.02)\end{array}$ & $\begin{array}{c}0.04 \\
(0.001)\end{array}$ & $\begin{array}{c}1.1 \\
(0.01)\end{array}$ & $\begin{array}{c}0.07 \\
(0.01)\end{array}$ \\
\hline Solid fraction & 7.2 & $\begin{array}{c}21.00 \\
(0.1)\end{array}$ & $\begin{array}{l}18.77 \\
(0.11)\end{array}$ & $\begin{array}{l}30.35 \\
(3.03)\end{array}$ & - & $\begin{array}{c}1.39 \\
(0.03)\end{array}$ & $\begin{array}{c}0.23 \\
(0.01)\end{array}$ & - & - \\
\hline
\end{tabular}

Table 2. Chemical characteristics of sludge, liquid and solid fraction by solid-liquid separation.

${ }^{\dagger}$ Total solid content, ${ }^{\ddagger}$ Volatile solid content, ${ }^{\S}$ Total chemical oxygen demand, ${ }^{\circledR}$ Soluble chemical oxygen demand, ${ }^{\S}$ Total nitrogen content, ${ }^{\int}$ Suspended solid content, ${ }^{\text {If }}$ Values in parentheses are standard deviations.

\begin{tabular}{|c|c|c|c|c|c|c|}
\hline Sample & $\mathrm{C}$ & $\mathrm{H}$ & $\mathrm{O}$ & $\mathrm{N}$ & $\mathrm{S}$ & $\mathrm{B}_{\mathrm{th}}{ }^{\dagger}$ \\
\hline & & ----- & $6(\mathrm{w} / \mathrm{y}$ & ------- & & $\mathrm{Nm}^{3} \mathrm{~kg}^{-1}-\mathrm{VS}_{\text {added }}$ \\
\hline Sludge & 56.6 & 8.6 & 14.6 & 5.2 & 0 & 0.81 \\
\hline Liquid fraction & - & - & - & - & - & - \\
\hline Solid fraction & 57.1 & 8.9 & 5.0 & 14.0 & 0.2 & 0.79 \\
\hline
\end{tabular}

Table 3. Elemental composition and theoretical methane potential of sludge, liquid and solid fraction by solid-liquid separation.

\footnotetext{
${ }^{\dagger}$ Theoretical methane potential.
} 


\section{실험적 메탄생산포텐셜(Ultimate methane potential; $\mathbf{B}_{\mathbf{u}}$ )} 공시시료에 대하여 70 일간의 메탄생산포텐셜 시험을 통해 얻은 누적 메탄생산 곡선은 Fig. 1과 같으며, Fig. 2와 Fig. 3 은 각각 VS와 COD 함량을 기준으로 표현한 메탄생산 수율

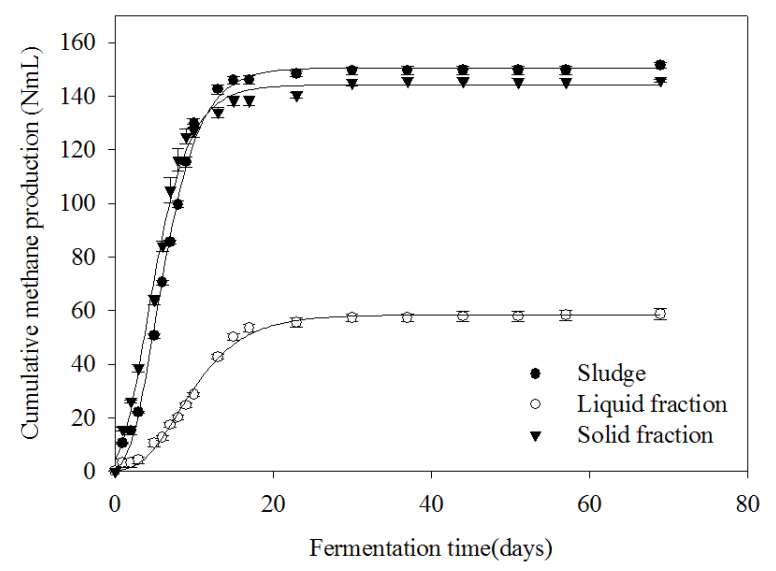

Fig. 1. Cumulative methane production curves obtained by BMP assay in sludge, liquid and solid fraction of sludge.

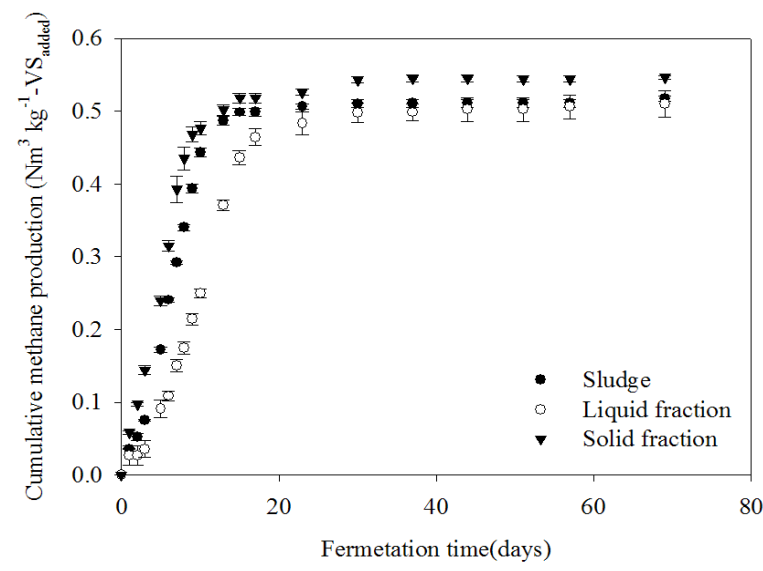

Fig. 2. Cumulative methane yields estimated at the basis of VS content in sludge, liquid and solid fraction of sludge.

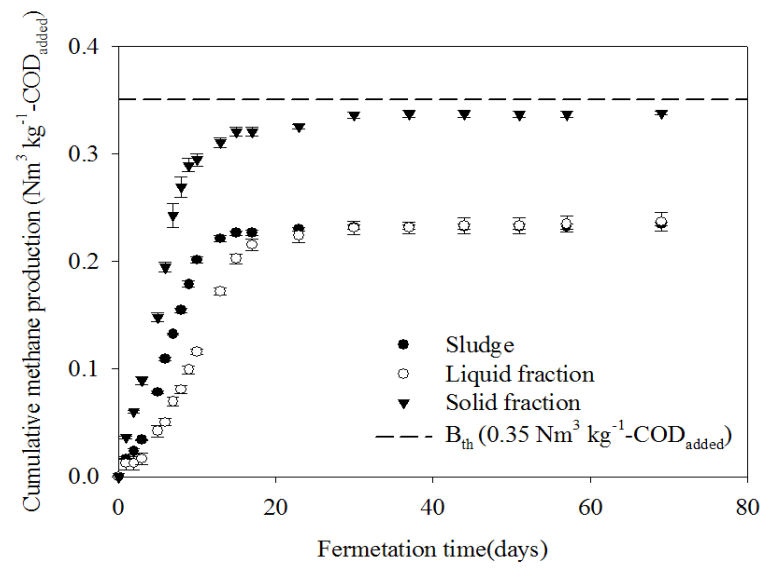

Fig. 3. Cumulative methane yields estimated at the basis of COD content in sludge, liquid and solid fraction of sludge.
을 보인다. 슬러지 시료와 슬러지의 고상과 액상 시료 모두 배양기간 20 일 정도에서 $95 \%$ 이상 메탄생산이 이루어 졌으 며, 배양기간 20 일 이후부터는 완만한 메탄 생산을 나타냈 다. 누적 메탄생산 곡선에서 슬러지의 경우 최대 메탄생산 량 $(\mathrm{P})$ 이 $151.12 \mathrm{~mL}$ 이었으며, 슬러지의 고상과 액상의 경우 각각 최대 메탄생산량 (P)이 59.94, $144.92 \mathrm{~mL}$ 로 나타났다. 일최대 메탄생산속도 $\left(\mathrm{R}_{\mathrm{m}}\right)$ 는 슬러지와 슬러지의 고상과 액 상에서 각각 $17.752,17.352,4.691 \mathrm{~mL}$ day $^{-1}$ 로 나타나 상대 적으로 슬러지 액상에서의 메탄생산 속도가 낮게 진행되었 다. 최대 메탄생산포텐셜 $\left(\mathrm{B}_{u}\right)$ 는 $\mathrm{VS}$ 함량을 기준으로 하는 경 우 슬러지, 슬러지 액상과 고상에서 각각 $0.52,0.52,0.55$ $\mathrm{Nm}^{3} \mathrm{~kg}^{-1}-\mathrm{VS}_{\text {added }}$ 로 나타나 비슷한 메탄퍼텐셜을 나타내었 으며, $\mathrm{COD}$ 함량을 기준으로 하는 경우 슬러지, 슬러지 액상 과 고상에서 각각 $0.24,0.23,0.33 \mathrm{Nm}^{3} \mathrm{~kg}^{-1}-\mathrm{COD}_{\text {added }}$ 로 나타나 슬러지 고상에서의 메탄퍼텐셜이 높은 수치를 보였 다. VDI 4630 (2006)에서는 회분식 혐기반응기로 투입한 유 입 $\mathrm{COD}$ 의 약 $7 \%$ 가 혐기소화 과정에서 혐기 미생물의 바이 오매스로 전환되는 것으로 간주한다. 따라서 이론적으로 투 입 $\mathrm{COD}$ 전량이 메탄으로 전환되는 경우 $0.35 \mathrm{Nm}^{3} \mathrm{~kg}^{-1}$ $-\mathrm{COD}_{\text {added }}$ (식 4) 알려져 있으나 실질적인 메탄 생산량은 혐 기 미생물의 바이오매스로 전환되는 부분을 제외하면 생산 퍼텐셜은 $0.326 \mathrm{Nm}^{3} \mathrm{~kg}^{-1}-\mathrm{COD}_{\text {added }}$ 퐁가ㄱㅏㅏㄹ 수 있다. 그러 므로 슬러지의 고상에서 나타난 최종메탄퍼텐셜 $0.33 \mathrm{Nm}^{3}$ $\mathrm{kg}^{-1}-\mathrm{COD}_{\mathrm{added}}$ 는 이론적인 메탄생산 포텐셜을 근소하게 초 과하는 것으로 판단된다. $\mathrm{COD}$ 기준으로 산출한 슬러지 고 상에서의 최종 메탄생산포텐셜 $\left(\mathrm{B}_{\mathrm{u}}-\mathrm{COD}\right)$ 이 높게 평가되는 이유는 상대적으로 슬러지나 슬러지 액상과 비교하여 TN과 $\mathrm{NH}_{4}{ }^{+}-\mathrm{N}$ 함량이 높은 슬러지 고상의 경우 $\mathrm{COD}$ 측정과정에 서 $\mathrm{NH}_{4}{ }^{+}-\mathrm{N}$ 에 의한 간섭으로 충분한 화학적 산화반응이 일 어나지 못하는 경우이다. $\mathrm{Kim}$ (1989)은 $\mathrm{COD}$ 측정에서 $\mathrm{NH}_{4}{ }^{+}-\mathrm{N}$ 의 간섭 영향을 평가하고 $\mathrm{COD}$ 측정 중 중크롬산 이 온 (dichromate)의 농도가 지속적으로 높게 유지되면서 유 기물의 분해 반응시간을 증가시킨다고 보고한 바 있다. 따 라서 다량의 단백질태 유기물과 암모니아태 질소를 포함하 는 슬러지 고상 시료의 경우 $\mathrm{COD}$ 측정시 $\mathrm{NH}_{4}{ }^{+}-\mathrm{N}$ 간섭으로 인하여 유기물의 산화반응이 불충분하여 낮은 $\mathrm{COD}$ 수치를 나타낸 것으로 생각된다.

혐기적 유기물 분해율 평가 유기물 함량을 달리하는 슬러지, 슬러지 고상과 액상의 유기물 구성특성과 혐기적 분해율을 분석한 결과 Table 5 와 같다. 슬러지의 경우 TS 중 VS의 비중이 $87.0 \%$ 로 나타났으며, 슬러지 액상은 TS 중 VS의 비중이 $80.8 \%$ 로 감소하였고, 슬러지 고상은 TS 중 VS 의 비중이 $89.4 \%$ 로 증가하였다. 슬러지 액상에서 상대적으 로 고정성 고형물 (Fixed solid; FS, FS=TS-VS)의 함량이 높은 것은 용액상 존재하는 염류로 인한 것이다. 또 VS 대 
Table 4. Model parameters by the modified Gompertz model and ultimated methane potentials estimated from the cumulative methane production data.

\begin{tabular}{|c|c|c|c|c|c|}
\hline \multirow{2}{*}{ Sample } & \multirow{2}{*}{$\mathrm{P}^{\dagger}$} & \multirow{2}{*}{$\mathrm{R}_{\mathrm{m}}{ }^{\ddagger}$} & \multirow{2}{*}{$\lambda^{\S}$} & \multicolumn{2}{|c|}{ Ultimate methane yield } \\
\hline & & & & $\mathrm{B}_{\mathrm{u}}-\mathrm{VS}^{\mathrm{I}}$ & $\mathrm{B}_{\mathrm{u}}-\mathrm{COD}^{\phi}$ \\
\hline & $\mathrm{mL}$ & $\mathrm{mL}$ day $^{-1}$ & day & $\mathrm{Nm}^{3} \mathrm{~kg}^{-1}-\mathrm{VS}_{\text {added }}$ & $\mathrm{Nm}^{3} \mathrm{~kg}^{-1}-\mathrm{COD}_{\text {added }}$ \\
\hline Sludge & 151.12 & 17.752 & 1.94 & $\begin{array}{c}0.52 \\
(0.005)^{\jmath}\end{array}$ & $\begin{array}{c}0.24 \\
(0.002)\end{array}$ \\
\hline Liquid fraction & 58.94 & 4.691 & 3.37 & $\begin{array}{c}0.52 \\
(0.014)\end{array}$ & $\begin{array}{c}0.23 \\
(0.008)\end{array}$ \\
\hline Solid fraction & 144.92 & 17.352 & 0.81 & $\begin{array}{c}0.55 \\
(0.001)\end{array}$ & $\begin{array}{c}0.33 \\
(0.001)\end{array}$ \\
\hline
\end{tabular}

${ }_{\dagger}^{\dagger}$ Methane production, ${ }^{\ddagger}$ Specific methane production rate, ${ }^{\S}$ Lag phase time, "Ultimated methane potential in the basis of VS content, ${ }^{\oint}$ Ultimated methane potential in the basis of COD content, ${ }^{f}$ Values in parentheses are standard deviations.

Table 5. Organic composition characteristics and anaenobic biodegradability in sludge, liquid and solid fraction of sludge.

\begin{tabular}{|c|c|c|c|c|c|}
\hline Sample & $\mathrm{VS} / \mathrm{TS}$ & TCOD/VS & SCOD/TCOD & $D_{V S}^{\dagger}$ & 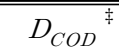 \\
\hline & \multicolumn{3}{|c|}{ 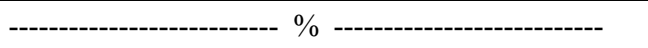 } & \multicolumn{2}{|c|}{ - $\%(\mathrm{w} / \mathrm{w})$} \\
\hline Sludge & 87.0 & 220.4 & 6.2 & $\begin{array}{l}76.31 a^{\S} \\
(1.76)^{\llbracket}\end{array}$ & $\begin{array}{c}73.43 a \\
(0.55)\end{array}$ \\
\hline Liquid fraction & 80.8 & 223.8 & 19.1 & $\begin{array}{l}76.30 \mathrm{a} \\
(2.68)\end{array}$ & $\begin{array}{l}74.01 \mathrm{a} \\
(2.65)\end{array}$ \\
\hline Solid fraction & 89.4 & 161.7 & - & $\begin{array}{l}77.04 a \\
(0.07)\end{array}$ & $\begin{array}{c}99.06 \mathrm{~b} \\
(0.29)\end{array}$ \\
\hline
\end{tabular}

${ }^{\dagger}$ Anaerobic biodegradability estimated in the basis of VS content, ${ }^{\ddagger}$ Anaerobic biodegradability estimated in the basis of COD content, ${ }^{\S}$ Means in the same column with different superscripts differ significantly $(\mathrm{p}<0.05)$, ${ }^{\mathrm{T}}$ Values in parentheses are standard deviations.

비 $\mathrm{TCOD}$ 의 비율은 슬러지 $220.4 \%$, 슬러지 액상 $223.8 \%$, 슬러지 고상 $161.7 \%$ 로 나타나 슬러지 고상의 TCOD 함량이 슬러지나 슬러지 액상과 비교하여 낮은 비율을 보이고 있 다. 슬러지, 슬러지 고상과 액상에서의 혐기적 유기물 분해 율은 VS 함량 기준의 경우 각각 76.31, 77.04, 76.30\%로 통 계적으로 차이가 없었으나, $\mathrm{COD}$ 함량 기준의 경우 73.43 , 99.06, 74.01\%로 슬러지 고상에서 높게 나타났다. COD 함 량을 기준으로 하는 경우에 슬러지 고상에서 $99.06 \%$ 의 높 은 혐기적 유기물 분해율을 나타낸 것은 앞에서 설명한 바 와 같이 슬러지 고상의 $\mathrm{COD}$ 함량이 낮게 평가된 데에서 비 롯하는 것으로 생각된다.

\section{Conclusion}

본 연구에서는 혐기소화공정의 설계 및 운전을 위한 중 요한 지표인 투입 유기물의 메탄생산포텐셜과 혐기적 유기 물의 분해율을 평가하는데 있어 유기물의 함량 수준이 미치 는 영향을 $\mathrm{VS}$ 와 $\mathrm{COD}$ 기준에서 각각 비교·분석하였다. 일반 적으로 가축분뇨, 음식물쓰레기, 하수슬러지 등과 같이 혐 기소화의 원료로 활용되는 유기성 바이오매스의 경우 대체 로 높은 질소함량을 보이고, 또 농축 또는 고액분리를 통해
유기물의 함량이 증가하는 경우 동시에 질소의 농축도 함께 진행되는 특성이 있다. 특히 혐기소화액의 경우에는 밀폐된 반응기 안에서 미생물 반응이 진행되므로 유기태의 질소가 암모니아태의 질소로 전환 축적된다. 따라서 혐기소화의 주 요 인자인 메탄생산포텐셜과 혐기적 유기물의 분해율을 평 가하는데 있어 상대적으로 화학적 간섭이온의 영향이 적은 $\mathrm{VS}$ 함량을 기준으로 평가하는 것이 합리적일 것으로 판단 된다.

\section{References}

Angelidaki, I., M. Alves, D. Bolzonella, L. Borzacconi, J.L. Campos, A.J. Guwt, S. Kalyuzhnyi, P. Jenicek, and J.B. vanLier. 2009. Defining the biomethane potential(BMP) of solid organic wastes and energy crops: a proposed protocol for batch assays. Water Sci. Technol. 59(5):927-934.

Angelidaki, I., M. Alves, D. Bolzonella, L. Borzacconi, J.L. Campos, A.J. Guwy, S. Kalyuzhnyi, P. Jenicek, and J.B. van Lier. 2009. Defining the biomethane potential(BMP) of solid organic wastes and energy crops: a proposed protocol for batch assays. Water Sci. Technol. 59(5):927-934.

APHA. 1998. Standard methods for the examination of water 
and wastewater, 20th ed.

ASTM. 2008. E2170-01 Standard test method for determining the anaerobic biodegradation potential of organic chemicals. American Society for Testing and Materials. West Conshohocken, PA.

Beuvink, J.M., S.F. Spoelstra, and R.J. Hogendrop. 1992. An automated method for measuring the time course of gas production of feedstuffs incubated with buffered rumen fluid. Neth. J. Agri. Sci. 40:401-407.

Boyle, W.C. 1976. Energy recovery from sanitary landfills-a review. In: Schlegel, H.G., and, J., Barnea (Eds.), Microbial Energy Conversion. Pergamon Press Oxford, 119-138.

Hungate, R.E. 1969. A roll tube method for cultivation of strict anaerobes. Norris, J.R., and D.W. Ribbons. Method in microbiology Vol. 38:117-132.

Kim, B.R. 1989. Effect of ammonia on COD analysis. Water Pollution Control Federation 61(5):614-617.

Kim, S.H., H.C. Kim, C.H. Kim, and Y.M. Yoon. 2010. The measurement of biochemical methane potential in the several organic waste resources. Korea J. soil Sci. Fert. 43(3):356-362.

Kim, S.H., H. Kim, S.Y. Oh, C.H. Kim, and Y.M. Yoon. 2012. Effect of substrate to inoculum ratio on biochemical methane potential in the thermal pretreatment of piggery sludge. Korea J. soil Sci. Fert. 45(4):532-539.
Owen, W.F., D.C. Stuckey, J.B. Healy, L.Y. Young, and P.L. MaCarty. 1979. Bioassay for monitoring biochemical methane potential and anaerobic toxicity. Water Res. 12:485-492.

Shelton, D.R. and J.M. Tiedje. 1984. General method for determining anaerobic biodegradation potential. Appl. \& Environ. Microbiol. 47:850-857.

Shin, K.S., C.H. Kim, S.E. Lee, and Y.M. Yoon. 2011. Biochemical Methane Potential of Agricultural Waste Biomass. Korea J. soil Sci. Fert. 44(5):903-915.

Shin, K.S., C.H. Kim, S.E. Lee, and Y.M. Yoon. 2011. Biochemical methane potential of agricultural waste biomass. Korea J. soil Sci. Fert. 44(5):903-915.

Sorensen, A.H., M. Winther-Nielsen, and B.K. Ahring. 1991. Kinetics of lactate, acetate and propionate in unadapted and lactate-adapted thermophilic, anaerobic sewage sludge: the influence of sludge adaptation for start-up of thermophilic UASB-reactors. Micro biol. biotechnol. 34:823-827.

VDI 4630. 2006. Fermentation of organic materials, characterisation of the substrates, sampling, collection of material data, fementation test. VDI-Handbuch Energietechnik.

Williams, A., M. Amat-Marco, and M.D. Collins. 1996. Pylogenetic analysis of Butyrivibrio strains reveals three distinct groups of species within the Clostridium subphylm of gram-positive bacteria. Int. J. Syst. Bacterol. 46:195-199. 